\title{
PHOTOREDUCTION OF CYTOCHROME b-559 AND PHOTOINHIBITION OF PHOTOSYSTEM II FROM HIGHER PLANTS: EFFECT OF Cu (II) INHIBITION.
}

\author{
Inmaculada Yruela, José J. Pueyo and Rafael Picorel \\ Estación Experimental de Aula Dei (C.S.I.C.). Apdo. 202. \\ E-50080 Zaragoza, Spain.
}

\section{Introduction}

The photosynthetic activity decreases when oxygenic organisms are exposed to prolonged illumination with high light intensities. This process, which includes the functional impairment of photosystem II (PSII) electron transport and the structural damage of one of the PSII reaction center (RC) proteins (Dl), is known as photoinhibition [1]. It seems clear that the primary target of photoinhibition is the PSII RC. However there is a great deal of controversy whether the continuous strong illumination damages the electron transport at the acceptor or the donor side of the PSII. Many data on photoinhibition have been obtained using modified PSII preparations where the electron transport at the donor side or the acceptor side of PSII is impaired by treatment with some reagents [2-4], however the region close to Pheo has received less attention in these kind of studies. Our previous works [5-7] have demonstrated that $\mathrm{Cu}(\mathrm{II})$ inhibits electron transport at the acceptor side of PSII close to Pheo- $\mathrm{Q}_{\mathrm{A}}$ domain and $\mathrm{Cu}(\mathrm{II})$-inhibited PSII centers are photochemically inactive. The application of photoinhibitory conditions to $\mathrm{Cu}$ (II)treated PSII samples and the comparison between these results and those of the intact systems can help to better understand the relationship between electron transport and photoinhibition .

\section{Procedure}

Oxygenic PSII-enriched membranes from sugar beet were isolated as described in ref. 5. Tris-treated PSII-enriched membranes were prepared by the method of Allakhverdiev et al. [8]. For cyt $b-559$ photoreduction measurements, samples (60 $\mu \mathrm{g}$ Chl. $\mathrm{mL}^{-1}$ ) in buffer containing $0.3 \mathrm{mM}$ sucrose, $10 \mathrm{mM} \mathrm{NaCl} \mathrm{mM} \mathrm{Hepes-}$ $\mathrm{NaOH}, \mathrm{pH} 7.8$ were incubated with $50 \mu \mathrm{M}\left(\mathrm{I}_{50} / \mathrm{RC}\right)$ and $125 \mu \mathrm{M}\left(2 \mathrm{I}_{50} / \mathrm{RC}\right)$ of $\mathrm{CuCl}_{2}$ for $10 \mathrm{~min}$ at $4{ }^{\circ} \mathrm{C}$. For photoinhibitory experiments, samples $(100 \mu \mathrm{g} \mathrm{Chl}$. $\mathrm{mL}^{-1}$ ) in $3 \mathrm{~mL}$ of buffer containing $0.3 \mathrm{mM}$ sucrose, $10 \mathrm{mM} \mathrm{NaCl}$ and $25 \mathrm{mM}$ Mes- $\mathrm{NaOH}, \mathrm{pH} 6.5$ were incubated with $250 \mu \mathrm{M}\left(\mathrm{I}_{50} / \mathrm{RC}\right)$ and $500 \mu \mathrm{M}\left(2 \mathrm{I}_{50} / \mathrm{RC}\right)$ 
of $\mathrm{CuCl}_{2}$ and inmediately exposed to heat filtered white light $\left(5,500 \mu \mathrm{E} \cdot \mathrm{m}^{2} \cdot \mathrm{s}^{1}\right)$ under constant stirring. The temperature was mantained at $25{ }^{\circ} \mathrm{C}$ or $4{ }^{\circ} \mathrm{C}$ (see figure legend) depending of the experimental conditions. Anaerobic conditions were achieved by the addition of $10 \mathrm{mM}$ glucose, $0.23 \mathrm{mg} / \mathrm{mL}$ glucose oxidase and $80 \mu \mathrm{g} / \mathrm{mL}$ catalase before light treatment and mantaining $\mathrm{N}_{2}$ bubling during illumination. The $\mathrm{Cu}$ (II)-inhibited samples were washed twice with $10 \mathrm{mM} \mathrm{NaCl}$ and $25 \mathrm{mM}$ Mes- $\mathrm{NaOH}, \mathrm{pH} 6.5$ and resuspended in the same buffer plus $0.3 \mathrm{M}$ sucrose after the illumination treatment and before oxygen evolution measurements. Oxygen evolution activity was measured with a Clark-type oxygen electrode [5]. The rate of DCIP photoreduction was spectrophotometrically monitored at $590 \mathrm{~nm}$. The photoreduction kinetics of cyt $b-559$ were measured at $560 \mathrm{~nm}$ in the second range in both aerobic and anaerobic conditions with a Beckman DU 640 spectrophotometer. SDS-PAGE was performed in $15 \%$ acrylamide gels containing $6 \mathrm{M}$ urea. After transfer to a nitrocellulose membrane, proteins were detected with a rabbit anti-D1 serum and goat anti-rabbit IgG coupled to horseradish peroxidase as a secondary antibody. The bands were quantified by densitometry.

\section{Result and Discussion}

We have studied the effect of $\mathrm{Cu}$ (II)-inhibition on the photoreduction of cytochrome $b-559$, loss of oxygen evolution activity and D1 degradation during aerobic and anaerobic photoinhibition. The effect of $\mathrm{Cu}(\mathrm{II})$ inhibition on the photoreduction of cyt $b-559$ is showed in Fig. 1 .
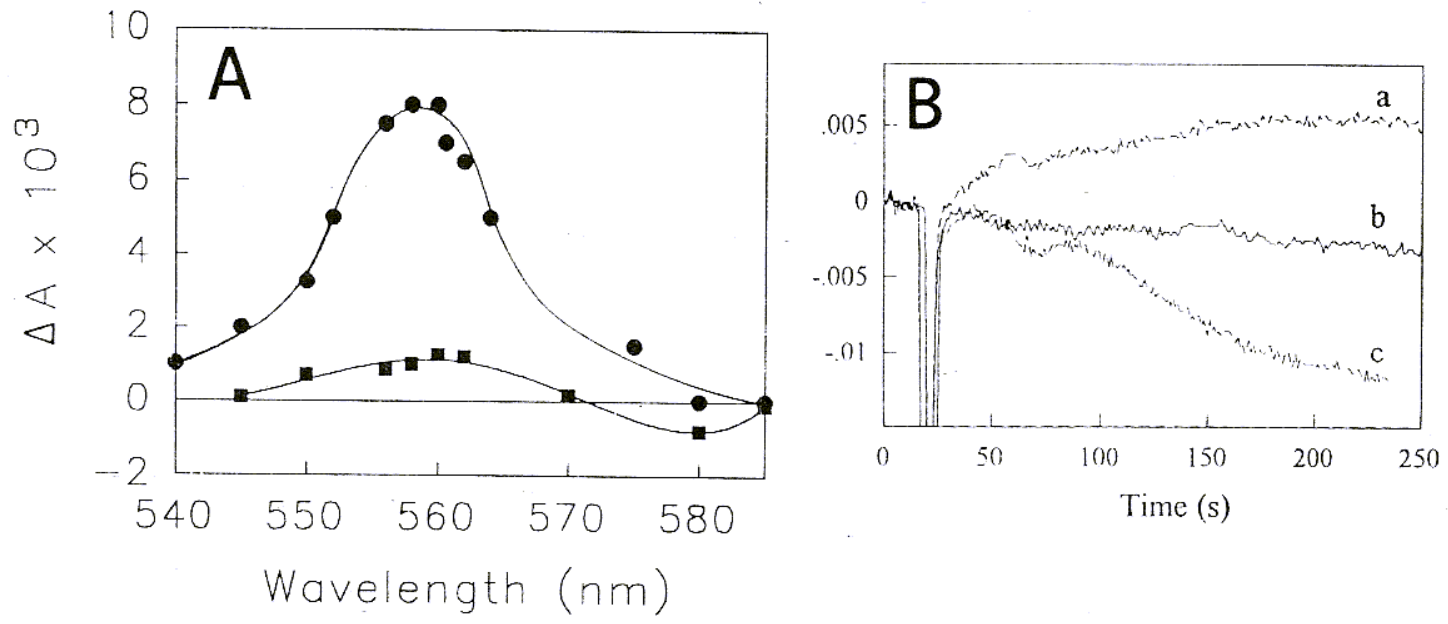

Figure 1.- A) Light-induced absorbance change in the spectral range 540$585 \mathrm{~nm}$ after $25 \mathrm{~s}$ of continuous illumination of dark-adapted PSII membranes at $\mathrm{pH} 7.8$ without addition $(9)$ and pre-incubated with $50 \mu \mathrm{M}$ $\mathrm{CuCl}_{2}\left(\mathrm{I}_{50} / \mathrm{RC}\right)$ ( for $10 \mathrm{~min}$. B) Time course of the light-induced absorbance change at $560 \mathrm{~nm}$ in the absence (a), and the presence of 50 $\mu \mathrm{M}\left(\mathrm{I}_{50} / \mathrm{RC}\right)(\mathrm{b})$ and $125 \mu \mathrm{M}\left(2 \mathrm{I}_{50} / \mathrm{RC}\right)(\mathrm{c})$ of $\mathrm{CuCl}_{2}$. 
The positive band centered at $560 \mathrm{~nm}$, which correspond to a fraction of $40 \%$ of total cyt $b$-559 reduced, decreased in $\mathrm{Cu}(\mathrm{II})$-inhibited samples (Fig 1A). The photoreduction kinetics of cyt $b-559$ in the $0-250 \mathrm{~s}$ range were also measured in the absence and presence of $\mathrm{Cu}(\mathrm{II})$. The PSII intact samples gave positive kinetics, however in the presence of increasing amounts of $\mathrm{CuCl}_{2}(>50 \mu \mathrm{M})$ negative kinetics were measured (Fig. 1B). This $\mathrm{Cu}$ (II) concentration corresponds to 75 $80 \%$ inhibition of oxygen evolution activity [5]. The data suggest that $\mathrm{Cu}(\mathrm{II})$ inhibits photoreduction of cyt b-559. The possible chemical interaction between cyt $b-559$ and $\mathrm{Cu}$ (II) was discarded based on the $\mathrm{Cu}$ (II) has no effect on the reduced minus oxidized spectrum (data not shown). In intact systems it has been proposed that cyt $b-559$ mediates cyclic electron transport within PSII where it is able to accept electrons from the reduced plastoquinone pool or the bound quinone $\mathrm{Q}_{\mathrm{B}}$ and then it can be oxidized directly via a monomeric chlorophyll. If we accept this function for cyt $b-559$ our results are consistent with the fact that the electron transport close to $Q_{A}$ niche is impaired in $\mathrm{Cu}(\mathrm{II})$-treated samples, as described in our previous works [5-7]. In addition to the $\mathrm{Cu}(\mathrm{II})$ effect on the photoreduction of cyt $b-559$, the data showed a second $\mathrm{Cu}(\mathrm{II})$ effect at higher $\mathrm{Cu}(\mathrm{II})$ concentrations $(>50 \mu \mathrm{M})$ which induces the photooxidation of cyt $b-559$.

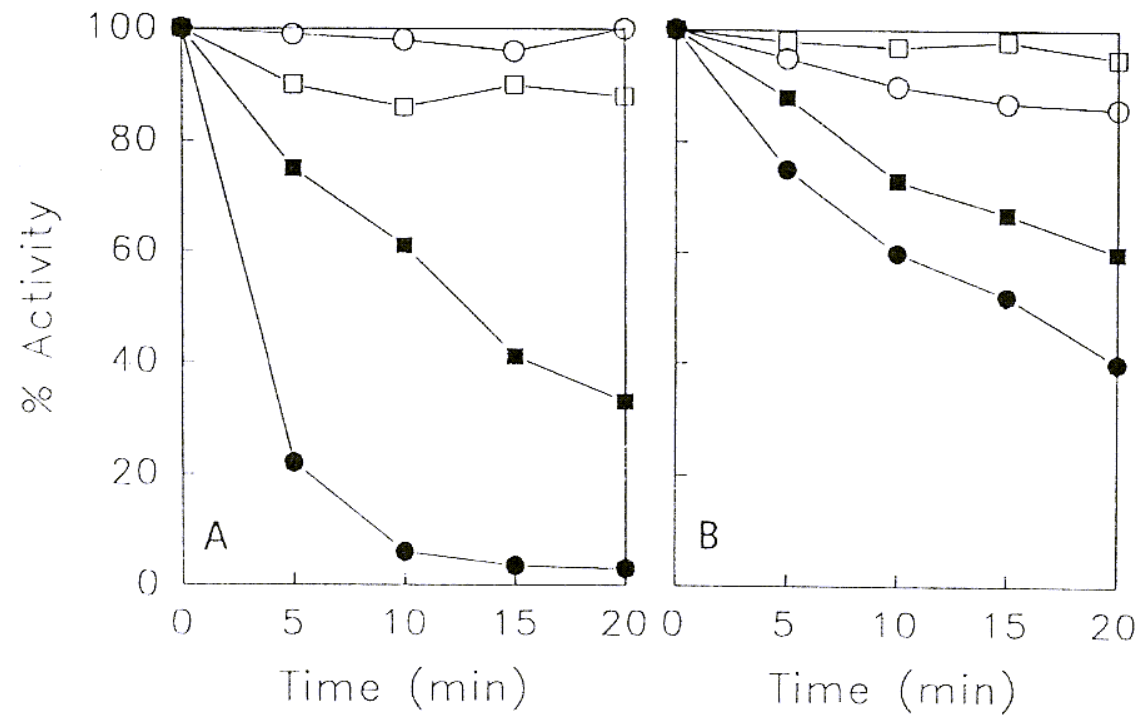

Figure 2.- Inhibition of oxygen evolution activity during aerobic (closed symbols) and anaerobic (open symbols) photoinhibition in the absence $(\mathbf{D}, \mathrm{D})$ and presence $(, \mathrm{O})$ of $250 \mu \mathrm{M} \mathrm{CuCl}_{2}\left(\mathrm{I}_{50} / \mathrm{RC}\right)$ at $(\mathrm{A}) 25^{\circ} \mathrm{C}$ and $(\mathrm{B})$ $4{ }^{\circ} \mathrm{C}$. Samples were washed twice before measurements. The $100 \%$ oxygen evolution activity without addition was about $560 \mu \mathrm{mol} \mathrm{O}_{2} \cdot \mathrm{mg} \mathrm{Chl}^{-1} \cdot \mathrm{h}^{-1}$ using DCBQ as electron acceptor.

The loss of oxygen evolution was markedly faster in $\mathrm{Cu}(\mathrm{II})$-treated PSII samples when the photoinhibitory experiments were done in the presence of oxygen at $25^{\circ} \mathrm{C}$ (Fig. 2A). However, similar kinetics were observed in anaerobic conditions. At $4{ }^{\circ} \mathrm{C}$ these differences were smaller and the loss of activity was slower than 
that at $25^{\circ} \mathrm{C}$ (Fig. 2B). It is known that photoinhibition is a temperature dependent phenomenum and it increases at higher temperatures [4]. A comparison of Fig. $1 \mathrm{~A}$ and $\mathrm{BB}$ indicates that the $\mathrm{Cu}(\mathrm{II})$ effect on photoinhibition is also temperature depending. After illumination, the presence of $\mathrm{Cu}$ (II) did not affect the Dl-protein degradation rate. In contrast, a faster degradation was measured in Triswashed PSII membranes (data not shown). These results indicate that the differences in the activity curves (Fig. 2) are unlikely to be due to the loss of the protein itself. D1 protein was degraded $20 \%$ after $10 \mathrm{~min}$ illumination while the loss of oxygen evolution activity in non-treated and $\mathrm{Cu}(\mathrm{II})$-treated PSII preparations was $40 \%$ and $92 \%$, respectively. The more pronounced impairement of the electron transport compared to Dl-protein degradation has also been described by others [3]. It seems, therefore, that $\mathrm{Cu}(\mathrm{II})$-inhibitory and Tristreatment effects are the consequence of two different molecular mechanisms. Since the Tris-treatment removes the extrinsic proteins that stabilize the manganese complex of the PSII donor side, it is possible to suggest in these experimental conditions that the $\mathrm{Cu}(\mathrm{II})$-inhibitory site is not located on the donor side of PSII. Moreover, the rate of DCIP-reduction in intact PSII samples decreased up to $50 \%$ and $68 \%$ after $15 \mathrm{~min}$ and $30 \mathrm{~min}$ of illumination, respectively. After these times, addition of $300 \mu \mathrm{M}$ DPC increased the rate of DCIP reduction, being then the loss of activity caused by photoinhibition of $9 \%$ and $13 \%$, respectively. The increment in the control DCIP-reduction rate (non illuminated) was $28 \%$. These findings provide the proportion that photoinhibition affects the electron transport on the donor side of PSII [2]. The addition of DPC to the photoinhibited Cu(II)-treated samples had no effect on the DCIP reduction indicating that photodamage in these $\mathrm{Cu}$ (II)-modified systems does not occur on the donor side of PSII.

\section{References}

1 Aro, E-M, Virgin, I. and Andersson, B. (1993) Biochim. Biophys. Acta 1143, 113-134.

2 Eckert, H-J, Geiken, B., Bernarding, J., Napiwotzki, A., Eichler, H.J. and Renger, G. (1991) Photosynth. Res. 27, 97-108.

3 Jegerschold, C., Virgin, I. and Styring, S. (1990) Biochemistry 29, 6179-6186.

4 Kirilovsky, D., Rutherford, A.W. and Etienne A-L (1994) Biochemistry 33, 3087-3095.

5 Yruela, I., Montoya, G., Alonso, P.J. and Picorel, R. (1991) J. Biol. Chem. 266, 22847-22850.

6 Yruela, I. Montoya, G. and Picorel, R. (1992) Photosynth. Res. 33, 227-233.

7 Yruela, I., Alfonso, M., Ortiz de Zarate, I., Montoya, G. and Picorel R. (1993) J. Biol. Chem. 268, 1684-1689.

8 Allakhverdiev, S.I., Karacan, M.S., Somer, G., Karacan, N., Khan, E.M, Rane,S.Y., Padhye, S., Klimov, V.V. and Renger, G. (1994) Biochemistry 33, 12210-12214. 